\title{
STUDIES IN FAT METABOLISM. II. EVALUATION OF THE EF- FECT OF TESTOSTERONE PROPIONATE UPON KETONE, CARBOHYDRATE, AND PROTEIN METABOLISM IN A PATIENT WITH DIABETES MELLITUS COMPLI- CATED BY THYROTOXICOSIS ${ }^{1,2}$
}

\author{
By LAURANCE W. KINSELL, SHELDON MARGEN, ${ }^{3}$ GEORGE D. MICHAELS, AND \\ DAVID P. MCCALLIE WITH THE TECHNICAL ASSISTANCE OF C. T. ANDERSON, \\ L. E. SUITER, V. T. THOMPSON, ${ }^{4}$ F. E. OLSON, AND \\ B. T. SIGNOROTTI
}

\begin{abstract}
(From the Metabolic Research Unit, University of California, U. S. Naval Hospital, Oakland, Cal.)
\end{abstract}

(Submitted for publication June 18, 1951; accepted August 27, 1951)

In 1937, Kochakian observed that testosterone compounds, when administered to castrate dogs, resulted in nitrogen retention (1). This coincided with the acquisition of a proportional amount of protein tissue in such animals. An identical effect in man was demonstrated by Kenyon and his co-workers (2), and subsequently by others including Albright, Brown, Butler, Howard, Talbot, Wilkins, and their respective co-workers.

Albright noted that the administration of testosterone to a fat man on a low caloric intake resulted in diminished nitrogen in the urine and cessation of weight loss (3) (Figure 1). ${ }^{5}$ The explanation of this phenomenon is not hard to find. The energy equivalent of protein tissue (which is about $80 \%$ water) is approximately 0.8 calorie per gm.; that of fat tissue (which contains only $10 \%$ water) is 8 to 9 calories. Therefore, $1 \mathrm{gm}$. of fat tissue yields approximately 10 times the number of calories obtainable from $1 \mathrm{gm}$. of protein tissue. An individual who spares protein tissue and who oxidizes fat tissue in an amount calorically equivalent

1 This work was supported in part by grants from the Schering Corporation; Research Division of the Bureau of Medicine and Surgery, U. S. Navy (BuMed No. 007046) and from the Office of Naval Research, under a contract between the latter and the University of California.

2 This paper was presented in part at a joint meeting of the American Diabetes Association and the Association for the Study of Internal Secretions at Atlantic City, New Jersey, on June 4, 1949.

3 Schering Research Fellow in Endocrinology, 19481949; Damon Runyon Clinical Research Fellow, 19491951.

$4 \mathrm{HM}_{1}, \mathrm{USN}$.

5 Used with the permission of Dr. Fuller Albright and the Josiah Macy, Jr. Foundation. to such protein tissue will consume only one-tenth the weight of tissue in the course of such oxidation. In other words, when one burns fat and builds

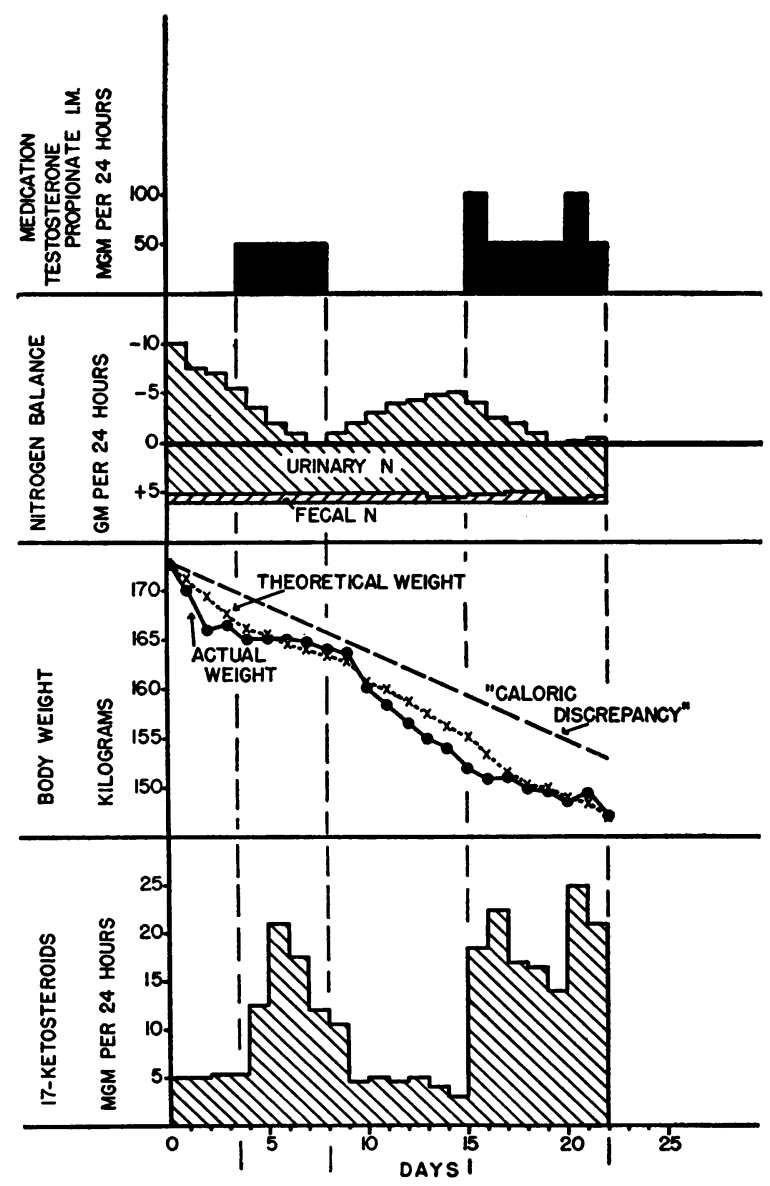

Fig. 1. Protein-sparing Action of Testosterone Propionate in an Obese Individual on a Low Calorie INTAKE

(Modified from Albright. ${ }^{5}$ ) 


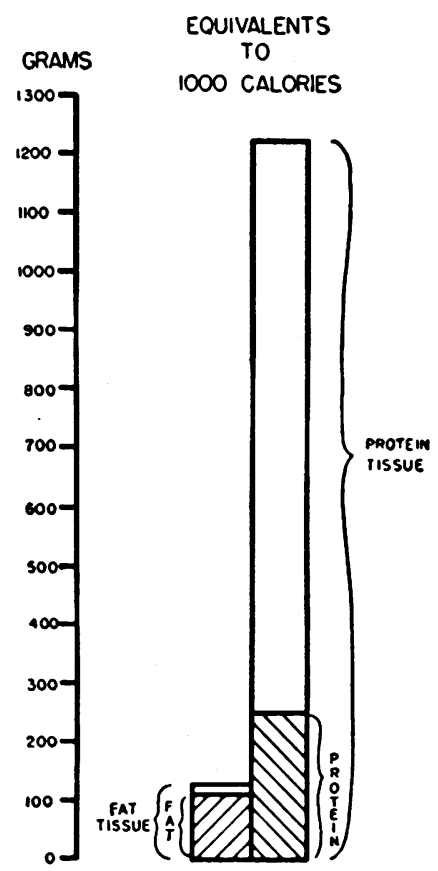

Fig. 2. Caloric Equivalents of Fat and Protein Tissue

It is apparent that the combustion of $1 \mathrm{gm}$. of fat tissue can spare more than 10 times that mass of protein tissue.

protein, he can lay down approximately $10 \mathrm{gm}$. of protein tissue for every gram of fat tissue which is oxidized. This is depicted diagrammatically in Figure 2.

An agent such as testosterone, therefore, which has a major protein anabolic effect, and which can exert a protein sparing action in individuals on a low calorie intake might produce such an effect by accelerating the rate of fat oxidation. The present investigation was designed to evaluate this possibility.

\section{EXPERIMENTAL CONDITIONS}

The patient selected for the study was a 27 year old male with severe diabetes, complicated by severe thyrotoxicosis (his basal metabolic rate was consistently in excess of plus $80 \%) .{ }^{\circ}$

The nature of the metabolic abnormalities made the production of any desired degree of ketonemia, ketonuria, hyperglycemia, and glycosuria a simple matter. Throughout the study, his dietary intake was in excess of $3900 \mathrm{cal}$ ories and consisted of $128 \mathrm{gm}$. of protein, $264 \mathrm{gm}$. of fat,

6 This patient was transferred to our service specifically for this study through the kindness of Dr. Gordon E. Hein and Dr. Felix Kolb of the Veterans Administration Hospital, San Francisco. and $259 \mathrm{gm}$. of carbohydrate. The diet was chemically constant throughout. Its composition was checked at regular intervals by chemical analyses of homogenized aliquots. Diet and crystalline insulin (155 units daily) were administered to him in five portions between the hours of 10:00 a.m. and 10:00 p.m. On this diet and on a program of constant activity, he was in weight equilibrium, and his urinary nitrogen averaged $19 \mathrm{gm}$. daily for a period of more than two weeks prior to the administration of any therapeutic agent other than insulin.

At 8:00 each morning ( 10 hours after the patient had received his last food and last insulin), fasting blood specimens were obtained for sugar and ketones. Twentyfour hour urine collections were divided into three component portions: the first, from 6:00 to 8:00 a.m.; the second, from 8:00 to 10:00 a.m.; and the third, from 10:00 a.m. to 6:00 a.m. the following morning. Sugar, total ketone, nitrogen, sodium, phosphorus, potassium, and other determinations were carried out in these specimens.

Respiratory quotient determinations were obtained between the hours of 8:00 and 9:00 a.m. daily. All respiratory quotient data are corrected for urinary sugar and urinary nitrogen.

\section{METHODS}

The urinary glucose was determined by Benedict's method (4), and the blood sugars by Nelson's modification of the Somogyi procedure (5). The blood and urinary ketones were quantitated by the method of Barnes and Wick (6) (this study was carried out prior to the development of the method of Michaels and associates, Paper I of this series), and the urinary nitrogens by the Kirk modification of the Kjeldahl procedure (7). Respiratory quotients were determined with the use of a closed circulating system in which the oxygen was measured by a precision wet test meter, and the carbon dioxide was absorbed in a solution of sodium hydroxide. The carbonate formed was quantitated in a Van Slyke manometric blood gas apparatus (8). As noted above, all respiratory quotient values were corrected for urinary sugar and for urinary nitrogen. The total amount of urinary ketones was not of sufficient magnitude to warrant the use of a correction factor.

\section{RESULTS OF METABOLIC STUDY}

In Figure 3 are shown the data dealing with urinary sugar, ketones, and nitrogen, fasting blood sugar and ketones, respiratory quotient, basal oxygen consumption, and daily weight, obtained over a period of 25 days in the man above described. Because of the length of the study, only four days of control are shown. The patient, however, had been in a state of essential equilibrium for a period of two weeks prior to the administra- 


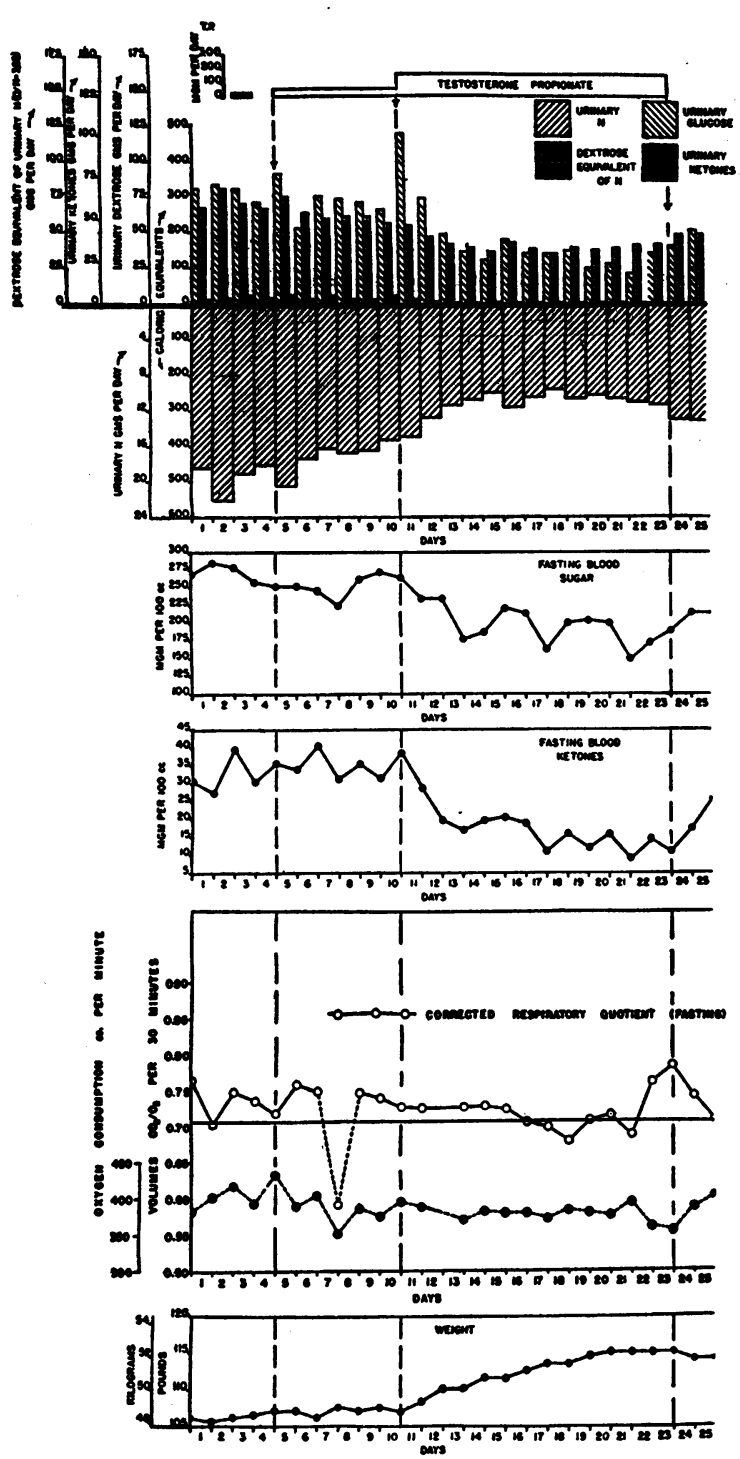

Fig. 3. The Efrects of Testosterone Propionate upon Blood and Urinary Sugar and Ketones, Urinary NItrogen, Respiratory QuOtIENT, Basal OXYgen CoNsumption, and Body Weight in Patient WEL

tion of testosterone. In chronological sequence, the observations are as follows :

\section{Pre-testosterone}

During this time the patient excreted approximately $75 \mathrm{gm}$. of glucose, $5 \mathrm{gm}$. of urinary ketones, and $19 \mathrm{gm}$. of urinary nitrogen, daily.

His fasting blood sugar averaged $275 \mathrm{mg} . / 100$ cc., and his fasting blood ketones, $35 \mathrm{mg} . / 100 \mathrm{cc}$. Non-protein respiratory quotients, as one would expect, averaged about 0.73 , a value compatible with almost exclusive fat combustion. (The respiratory quotient was obtained after complete abstinence from food or insulin for a perind of more than 10 hours.) The patient's weight during this time averaged 106 pounds with minor fluctuations.

\section{Response to $50 \mathrm{mg}$. of testosterone propionate ${ }^{7,8}$}

Except for a slight decrease in urinary nitrogen and urinary sugar and slight weight gain, no significant changes were noted during the six days that the patient received this dose of testosterone propionate. We have no explanation for the single bizarre respiratory quotient of 0.59 .

\section{Response to the administration of $150 \mathrm{mg}$. of testosterone propionate daily}

In previous experience with the use of testosterone in normal individuals and in patients with various metabolic abnormalities, we have felt that $50 \mathrm{mg}$. of testosterone propionate daily produced almost as great metabolic effects as would larger dosage. In this man the following changes immediately followed the administration of $150 \mathrm{mg}$. of testosterone propionate daily, whereas as noted above, the smaller dose produced minimal changes in this portion of the metabolic pattern:

1. Urinary sugar, after an increase to approximately $125 \mathrm{gm}$. on the first day of the large dose of testosterone, fell steadily to values approximating $25 \mathrm{gm}$. of glucose daily.

2. Urinary nitrogen decreased to an average level of $10 \mathrm{gm}$. daily, that is, to approximately half the amount excreted prior to the administration of testosterone.

3. Fasting blood sugar fell as low as $150 \mathrm{mg}$./ $100 \mathrm{cc}$.

4. Fasting blood ketones fell from their previous high levels to average values of $10 \mathrm{mg} . / 100 \mathrm{cc}$.

5. Urinary ketones reached negligible levels.

7 Grateful acknowledgment is made to Dr. Edward Henderson, Research Director, Schering Corporation, for generous supplies of testosterone propionate (Oreton) used in this study.

8 Testosterone propionate was administered intramuscularly. During the time of administration of $150 \mathrm{mg}$. daily, $50 \mathrm{mg}$. were given at 3 and 6 a.m., and $25 \mathrm{mg}$. at 10:00 a.m. and 10:00 p.m. 
6. The corrected (non-protein) respiratory quotient fell to values which on some occasions were below 0.71 .

7. Basal oxygen consumption did not change significantly. It was, however, subject to less daily fluctuation. This could be accounted for by the greatly improved clinical status of the patient.

8. Weight gain of 10 pounds occurred during the 13 days that the patient received $150 \mathrm{mg}$. of testosterone propionate daily.

\section{Clinical status of the patient}

Prior to the administration of testosterone, he had been very irritable in the early morning. This perhaps was attributable in part to the lack of adequate carbohydrate combustion and to the moderate ketosis. Within the three days following the beginning of testosterone administration, a most impressive change occurred in the clinical picture. He awakened spontaneously, was thoroughly cooperative, and, although still quite hyperkinetic (as one would expect in any individual with a basal metabolic rate in excess of plus 80), became a model patient. Prior to this, quite close supervision had been necessary to make sure that diet, activity, and medication were constant.

\section{Additional studies}

In addition to the studies just noted, determinations of urinary phosphorus, potassium, sodium, and other constituents were carried out during the first 25 days and also during periods of withdrawal and resumption of testosterone administration and administration of other hormonal agents. These studies will be described elsewhere in conjunction with similar studies in patients with uncomplicated thyrotoxicosis and uncomplicated diabetes. Suffice it to say for the present, that when testosterone was withdrawn prompt "rebound" occurred in terms of increased urinary nitrogen, sugar, ketones, and rapid deterioration in the clinical status of the patient.

\section{DISCUSSION}

The administration of testosterone propionate in adequate dosage to a patient with severe diabetes mellitus, associated with severe thyrotoxicosis, produced major metabolic changes which may be summarized as follows :
1. Little or no decrease in basal oxygen requirement.

2. Inhibition of protein catabolism, as manifested by decrease in nitrogen excretion, to approximately two-thirds of the previous amount.

3. A rapid fall in fasting blood sugar, and a decrease in urinary sugar excretion to less than onehalf the previous amount.

4. A fall in fasting blood ketones to less than $25 \%$ of the previous values, and an equivalent fall in urinary ketone excretion.

5. Rapid weight gain roughly proportional to the decrease in nitrogen excretion.

6. Fasting, non-protein, respiratory quotient values compatible with nearly exclusive fat combustion.

Interpretation of the preceding observations is not too simple. A portion of the interpretations must at the present time be speculative.

\section{Factual interpretations}

1. The energy requirement in this patient was not diminished.

2. The fall in fasting blood sugar and in urinary sugar appears to be attributable largely or entirely to decreased protein catabolism. Inspection of Figure 1 reveals that the decrease in urinary sugar and the fall in dextrose equivalent of nitrogen $(\mathrm{D} / \mathrm{N}=3.65)$ are reasonably parallel.

3. Consequently there was little or no increased energy derived from glucose inasmuch as the changes in blood sugar could be accounted for almost entirely on the basis of decreased carbohydrate formation rather than increased carbohydrate utilization.

4. Since the patient actually gained weight, had no increased calories available from carbohydrate, diminished calories available from protein, and had no decrease in energy requirement, it appears that he must of necessity have had an increased catabolism of fat.

5. Despite such increased fat catabolism, the blood and urinary ketones fell to an extreme degree.

\section{Speculative interpretations}

The observation of decreased blood and urinary ketones despite an increase in fat catabolism suggests that testosterone propionate in this patient may have: 
1. Decreased the rate of ketone formation from fatty acids, or

2. Increased the rate of ketone utilization.

Other studies will attempt to elucidate the mechanisms involved.

\section{SUMMARY}

A patient with severe diabetes mellitus associated with severe thyrotoxicosis, on a chemically constant dietary intake and constant insulin therapy, during the administration of $150 \mathrm{mg}$. of testosterone propionate daily manifested a fall in urinary sugar, nitrogen, and ketones of quite marked degree.

It is suggested that under these experimental conditions, the changes observed may have been due in part at least to a direct effect of testosterone upon fat or ketone metabolism.

\section{REFERENCES}

1. Kochakian, C. D., Testosterone and testosterone acetate and the protein and energy metabolism of castrate dogs. Endocrinology, 1937, 21, 750.
2. a. Kenyon, A. T., Knowlton, K., Sandiford, I., Koch, F. C., and Lotwin, G., A comparative study of the metabolic effects of testosterone propionate in nor$\mathrm{mal} \mathrm{men}$ and women and in eunuchoidism. Endocrinology, 1940, 26, 26.

b. Kenyon, A. T., Knowlton, K., and Sandiford, I., The anabolic effects of the androgens and somatic growth in man. Ann. Int. Med., 1944, 20, 632.

3. Albright, F. (as cited by Reifenstein, E. C.), Conferences on Metabolic Aspects of Convalescence, Including Bone and Wound Healing. Transactions of the Fifth Meeting, Josiah Macy, Jr. Foundation, Oct. 8-9, 1943, 74.

4. Benedict, S. R., The detection and estimation of glucose in urine. J. A. M. A., 1911, 57, 1193.

5. Nelson, N., A photometric adaptation of the Somogyi method for the determination of glucose. J. Biol. Chem., 1944, 153, 375.

6. Barnes, R. H., and Wick, A. N., A method for determination of blood acetone bodies. J. Biol. Chem., 1939, 131, 413.

7. Kirk, P. L., A one-piece glass micro-Kjeldahl distillation apparatus. Indust. \& Engin. Chem., Analyt. Ed., 1936, 8, 223.

8. Van Slyke, D. D., and Sendroy, J., Jr., Carbon dioxide factors for the manometric blood gas apparatus. J. Biol. Chem., 1927, 73, 127. 